\title{
MENINGKATKAN KEMAMPUAN DAN KETERAMPILAN SISWA DALAM MEMBACA PUISI MELALUI METODE DEMONSTRASI
}

( Penelitian Tindakan Kelas Mata Pelajaran Bahasa Indonesia di Kelas V SD Negeri Talun Kecamatan Cipatat Kabupaten Bandung Barat Tahun Pelajaran 215-2016)

\author{
1)Susilowati \\ ${ }^{1)}$ SDN Karangmulya, Cipatat Bandung Barat \\ Email: susilowati_2016@yahoo.com
}

\begin{abstract}
This study aimed fatherly improve the quality of guidance and counseling program at the high school level with a focus issue focused on improving Tutoring Service Orientation Learning can be overcome anxiety students choose majors in high school and what efforts can be done counselor in helping students for placement and majors.

The study design is described in a spiral of action research based on the adaptation of Hopkins with two cycles and each cycle of four phases of activity. Based on research data processing is found that the implementation of the guidance service learning orientation can overcome the anxiety level of students in the selection of majors in high school. This is evidenced by the level of student anxiety before any action guidance to the class X.3 in SMA Negeri 1 Bojongmangu amounted to $76.32 \%$. After the action guidance of experienced reductions of students who experience anxiety. It was assest with the percentage decrease from the first cycle, up to the second cycle of $34.21 \%$. Activity in the study orientation guidance services provides guidance information in groups major classical and small discussion groups. The results of this study are useful to enhance the role of coaching and guidance counselor in helping students with guidance and program implementation counselingg in SMAN 1 Bekasi regency, in particular, Bojongmangu.
\end{abstract}

Keywords: Poetry, Demonstration, Indonesia language

\section{A. PENDAHULUAN}

Bahasa Indonesia merupakan salah satu disiplin ilmu sekaligus sebagai alat untuk mencapai dan menyerap ilmu pengetahuan pada lembaga pendidikan formal maupun nonformal. Diarahkan untuk meningkatkan kemampuan peserta didik untuk berkomunikasi dalam bahasa Indonesia dengan baik dan benar, baik secara lisan maupun tulis, serta menumbuhkan apresiasi terhadap hasil karya kesastraan manusia Indonesia. (Depdiknas, 2008 : 106 ) . Dalam Bahasa Indonesia mencakup empat keterampilan berbahasa, yaitu keterampilan menyimak, berbicara, membaca dan menulis. Keempat keterampilan itu merupakan cater tunggal yang saling berkaitan dan mengisi, juga setiap keterampilan itu erat sekali berhubungan dengan proses berpikir yang mendasari bahasa.

Menurut Tarigan (1990 :7-9 ),

" Membaca adalah suatu proses yang dilakukan pembaca untuk memperoleh pesan yang hendak disampaikan oleh penulis melalui media kata-kata atau bahasa tulis". Tujuan utama membaca adalah untuk mencari serta memperoleh informasi 
mencakup isi dan memahami makna bacaan. Jelaslah bahwa pesan yang dimaksud oleh tarigan adalah berbagai informasi yang disajikan dalam bentuk tulisan.

Kegagalan pembelajaran membaca puisi pada siswa kelas $\mathrm{V}$ SD Negeri Talun, yaitu $60 \%$ siswa nilainya di bawah Kriteria Ketuntasan Minimal ( KKM ) yang telah ditetapkan yaitu 70. Oleh karena itu, maka penulis berpandangan perlunya diadakan penelitian dengan memberikan altematif penggunaan metode pengajaran dalam pembelajaran Bahasa Indonesia tentang membaca puisi dengan judul "Meningkatkan Kemampuan dan Keterampilan Siswa dalam Membaca Puisi melalui Metode Demonstrasi", dalam proses pembelajaran Bahasa Indonesia. Permasalahan penelitian ini penulis jabarkan ke dalam beberapa sub masalah, yaitu:

1. Apakah metode demonstrasi dapat meningkatkan kemampuan dan keterampilan siswa dalam membaca puisi ?

2. Bagaimana proses peningkatan kemampuan dan keterampilan siswa kelas $\mathrm{V}$ dalam membaca puisi sebelum dan sesudah menggunakan metode

Tujuan Penelitian ini adalah :

1. Mengukur kemampuan siswa kelas V dalam membaca puisi melalui metode Demonstrasi.

2. Untuk mengetahui dampak peningkatan kemampuan siswa kelas V dalam membaca puisi sebelum dan sesudah menggunakan metode demonstrasi.

3. Meningkatkan kemampuan dan keterampilan siswa kelas $\mathrm{V}$ dalam membaca puisi melalui metode demonstrasi.

Hasil penelitian ini diharapkan memberikan manfaat bagi berbagai pihak diantaranya akan dapat memotivasi siswa untuk terlibat aktif, kritis, dan inovatif dalam pembelajaran Bahasa Indonesia khususnya membaca puisi serta siswa dapat memperoleh kemampuan konseptual dalam membaca puisi.

\section{B. KAJIAN LITERATUR}

\section{Pengertian Metode Demonstrasi}

Metode demonstrasi adalah metode mengajar dengan cara memperagakan barang, kejadian, aturan, dan urutan melakukan suatu kegiatan, baik secara langsung maupun melalui penggunaan media pengajaran yang relevan dengan pokok bahasan atau materi yang sedang disajikan. ( Muhibbin Syah,2000).

Metode demonstrasi adalah metode yang digunakan untuk memperlihatkan sesuatu proses atau cara kerja suatu benda yang berkenaan dengan bahan pelajaran. ( Syaiful Bahri Djamarah, 2000 ). Manfaat Psikologis Pedagogis dari 
Metode

Demonstrasi

diantaraynay perhatian siswa dapat lebih dipusatkan; Proses belajar siswa lebih terarah pada materi yang sedang dipelajari; Pengalaman dan kesan sebagai hasil pembelajaran lebih melekat dalam diri Siswa. ( Daradjat, 1985 ). Kelebihan Metode Demonstrasi dalam Pembelajaran Membaca Puisi

1). Siswa dapat secara langsung mengamati bentuk pembacaan puisi.

2). Siswa dapat secara langsung mengetahui pelafalan kata, intonasi dalam membaca puisi dengan baik.

3). Siswa dapat secara langsung mengetahui pentingnya interpretasi, penampilan ketika membaca puisi.

4). Suasana kelas akan lebih hidup karena menghilangkan kejenuhan serta dapat dijadikan sebagai hiburan.

\section{Pengertian Membaca}

Membaca merupakan faktor yang sangat penting dalam kehidupan kita, karena lewat membaca kita menyerap berbagai informasi yang diperlukan. Menurut Tarigan, " membaca dapat diartikan sebagai proses perbuatan yang dilakukan dengan sadar dan bertujuan untuk mengenal lambang-lambang yang disampaikan penulis untuk menyampaikan makna ". ( Tarigan 1989: 118 ).

Selanjutnya, Tarigan mengungkapkan bahwa " membaca adalah suatu proses yang dilakukan serta dipergunakan oleh pembaca untuk memperoleh kesan, yang hendak disampaikan oleh penulis melalui media kata-kata / bahasa tulis ".( Tarigan , $1990: 7$ ). Tampubolon mengungkapkan bahwa " membaca adalah satu dari empat kemampuan pokok dan merupakan satu bagian komponen dari komunikasi Tulisan ". ( Tampubolon, 1990 : 5 ). Membaca adalah aktivitas pencarian informasi melalui lambang-lambang tertulis". ( Endang dalam Tarigan 1989: 133 ).

\section{Pengertian Puisi}

Secara etimologis istilah puisi berasal dari kata Yunani poesis, yang berarti membangun, membentuk, membuat, menciptakan. Sedangkan kata poet dalam tradisi Yunani Kuno berarti orang yang mencipta melalui imajinasinya, orang yang hampirhampir menyerupai dewa atau yang amat suka kepada dewadewa. Menurut Karnus Istilah Sastra, puisi merupakan ragam sastra yang bahasanya terikat oleh irama, matra, rima, serta penyusunan larik dan bait. (Sudjiman,1984 ). Watt-Dunton mengatakan bahwa puisi adalah ekspresi yang kongkret dan yang bersifat artistik dari pikiran manusia dalam bahasa emosional dan berirama.( Watt-Dunton dalam Situmorang, 1980 : 9 ). Herman J . Waluyo mendefinisikan bahwa puisi adalah bentuk karya sastra yang mengungkapkan pikiran dan perasaan penyair secara imajinatif dan disusun dengan mengkonsentrasikan semua kekuatan bahasa dengan pengonsentrasian struktur fisik dan struktur batinnya 


\section{METODOLOGI PENELITIAN}

Metode yang dipergunakan dalam penelitian ini adalah Deskriptif Analitik melalui Penelitian Tindakan Kelas, yaitu studi yang digunakan untuk mengumpulkan data, mendeskripsikan, mengolah, menganalisa, menyimpulkan dan menafsirkan data sehingga memperoleh gambaran yang sistematis. Penelitian Tindakan Kelas ini dilaksanakan di SD Negeri Talun Kecamatan Cipatat Kabupaten Bandung Barat. Sebagai subjek penelitian adalah kelas $\mathrm{V}$ jumlah siswa sebanyak 46 orang terdiri dari 18 orang siswa laki-laki, dan 28 orang siswa perempuan.Kelas tersebut dipakai sebagai subjek penelitian karena berdasarkan temuan dalam proses belajar sering ditemukan siswa yang kurang aktif dalam belajar, serta rendahnya perolehan nilai membaca puisi dalam pelajaran Bahasa Indonesia, yaitu siswa yang mencapai Kriteria Ketuntasan Minimal ( KKM ) hanya $40 \%$, hasil belajarnya masih belum memuaskan, oleh karena itu memerlukan penanganan yang segera. Penelitian ini dilaksanakan pada semester ganjil tahun pelajaran 2015- 2016, dari bulan Juli sampai dengan bulan Desember 2015. Waktu yang diperlukan untuk pembelajaran materi membaca puisi adalah 8 jam pelajaran, dalam satu minggu 2 jam pelajaran, setiap jam berlangsung tatap muka selama 35 menit. Instrumen Penelitian, Angket
Siswa; Angket merupakan alat pengumpul data melalui daftar tertulis yang disusun dan disebarkan untuk mendapat informasi atau keterangan dari sumber data ( responden ). Dalam penelitian ini sebagai respondennya adalah siswa kelas V SD Negeri Talun Kecamatan Cipatat Kabupaten Bandung Barat . Lembar observasi disusun untuk memperoleh gambaran langsung tentang kondisi pelaksanaan kegiatan penelitian di dalam kelas. Obsevasi tindakan dilakukan oleh guru lain yang bertindak sebagai obsever. Lembar observasi disusun untuk mengamati peneliti dalam melaksanakan tindakan kelas, kondisi kelas, dan aktivitas siswa dalam proses pembelajaran. Lembar Kerja Siswa yaitu lembar tugas yang berisi sejumlah soal yang harus dikerjakan secara kelompok. Tahapan refleksi merupakan tahapan pengkajian tindakan yang dilakukan secara menyeluruh, mulai dari perencanaan, pelaksanaan tindakan, sampai pengamatan. Dari uraian prosedur penelitian di atas untuk lebih memudahkan memahami pelaksanaan penelitian, maka peneliti mencoba menggambarkan langkahlangkah penelitian model John Elliot (Muslihuddin, 2016: 72 ).

\section{HASIL DAN PEMBAHASAN}

\section{Siklus-1}




\section{Kegiatan Pendahuluan}

Berdasarkan hasil Penelitian

Tindakan Kelas yang peneliti lakukan diperoleh data hasil tes siswa pada pelajaran bahasa Indonesia tentang membaca puisi. Data tersebut adalah data prestasi hasil belajar siswa yang tidak diberi perlakuan dengan data prestasi hasil belajar siswa yang diberi perlakuan. Sebelum dilakukan Penelitian Tindakan Kelas, peneliti melakukan observasi awal tentang prestasi pelajaran Bahasa Indonesia, ternyata dari hasil observasi menunjukkan bahwa nilai prestasi hasil belajar siswa khususnya pelajaran bahasa Indonesia tentang membaca puisi sangat rendah.

Berdasarkan hasil observasi yang telah peneliti lakukan selama proses pembelajaran berlangsung, maka peneliti melakukan tes awal ( Pra PTK ) untuk mengukur tingkat keberhasilan dan membandingkan perolehan nilai prestasi belajar siswa, bentuk tes yang diberikan adalah tes perbuatan. Tes awal dilakukan pada hari Senin, tanggal 3 Agustus 2015, pada siswa kelas V SD Negeri Talun. Kegiatan pada tes awal siswa disuruh kedepan untuk membacakan sebuah puisi, dan aspek yang dinilai adalah volume / suara, intonasi, dan ekspresi. Perolehan nilai tes awal ini akan dijadikan bahan acuan untuk mengetahui peningkatan hasil prestasi belajar siswa sesudah dan sebelum menerapkan metode demonstrasi dalam pelajaran bahasa Indonesia khususnya membaca puisi. Adapun nilai yang diperoleh siswa pada tes awal ( Pra PTK) adalah sebagai berikut . Dan hasil tes awal pada materi membaca puisi sebelum diadakan tindakan pada siklus 1 sesuai dengan tabel 4.1 diperoleh gambaran bahwa nilai rata-rata hasil belajar siswa adalah 65,41, sedangkan nilai tertinggi yang diperoleh siswa 74, dan nilai terendah 55. Nilai ideal yang mungkin dicapai siswa adalah 100, dan nilai terendah adalah 10 , dengan kriteria ketuntasan minimal ( KKM ) 70. Siswa yang nilai prestasi belajamya diatas KKM hanya 17 orang atau $36,9 \%$ dari total siswa 46 orang, sedangkan yang belum tuntas ada 29 orang atau $63,1 \%$. Hal ini memberikan gambaran bahwa prestasi belajar siswa pada mata pelajaran Bahasa Indonesia tentang " Membaca Puisi " masih tergolong rendah .

Berdasarkan hasil analisis dan refleksi yang dilakukan oleh peneliti sesuai di atas, ditemukan beberapa kekurangan pada aspek penyusunan rancangan pelaksanaan pembelajaran antara lain sebagai berikut :

1) Sikap dan aktivitas siswa masih kurang konsentrasi atau tidak fokus saat mengikuti proses pembelajaran.

2) Kegiatan siswa masih belum aktif. 
3) Penghayatan siswa terhadap puisi yang dibacakan masih kurang.

4) Menyuarakan kata-kata dengan artikulasi dan intonasi kurang jelas.

5) Ekspresi dan penjiwaan terhadap puisi masih kurang.

6) Penampilan masih terlihat malu-malu.

Berdasarkan hasil tersebut di atas, peneliti memutuskan untuk menggali kekurangan, kelemahan, dan kelebihan yang terjadi dalam proses pembelajaran, kemudian peneliti deskripsikan sebagai bahan untuk mencari altematif tindakan pada siklus 1. Siklus I dilaksanakan dua kali pertemuan, pertemuan kesatu dilaksanakan pada hari Jum'at, tanggal 14 Agustus 2015 pada jam ke 1 dan ke 2 selama 70 menit di kelas V. Sedangkan ulangan siklus ke 1 dilaksanakan pada pertemuan ke dua, yaitu pada hari Senin tanggal 24 Agustus 2015, jam ke 5 dan ke 6 selama 70 menit, dan bentuk tes dalam ulangan siklus 1 adalah tes perbuatan melalui metode demonstrasi, dimana siswa tampil di depan kelas untuk membacakan sebuah puisi. Untuk lebih jelasnya kegiatan yang dilakukan selama proses pembelajaran pada siklus 1 adalah sebagai berikut :

\section{Perencanaan}

\begin{tabular}{lr}
\multicolumn{1}{c}{ Dalam tahap } \\
perencanaan ini & $\begin{array}{r}\text { peneliti } \\
\text { perangkat }\end{array}$ \\
mempersiapkan & pembelajaran yang di butuhkan
\end{tabular}

yaitu :

1) Membuat Rencana

Pelaksanaan

Pembelajaran ( RPP ), dengan pokok bahasan membaca puisi.

2) Membuat lembar observasi terhadap guru dan siswa. Lembar observasi ini digunakan untuk melihat aktivitas guru dan siswa ketika proses belajar mata pelajaran Bahasa Indonesia berlangsung, hal ini pun memberi masukan kepada peneliti dalam penyusunan lembar kegiatan siswa ( LKS ).

3) Membuat angket siswa.

4) Membuat lembar kerja siswa ( LKS ).

5) Membuat alat evaluasi untuk tes pada tindakan siklus 1 .

\section{Tindakan}

Pada bagian ini akan diuraikan mengenai pelaksanaan tindakan yang mengacu pada skenario pembelajaran dan LKS, yaitu :

1) Mengecek kehadiran siswa untuk menetapkan jumlah siswa yang mengikuti kegiatan belajar, pada siklus 1 ini kehadiran peserta didik 100\% yaitu 46 orang.

2) Mengkondisikan siswa 
agar siap menerima

pelajaran.

3) Memberikan

apersepsi

pembelajaran

agar peserta didik

dapat mengingat

kembali materi

yang telah

diberikan

sebelumnya.

4) Membenamkan

motivasi agar peserta

didik mampu terlibat

aktif dalam seluruh

proses pembelajaran.

5) Menginformasikan

kriteria ketuntasan

minimal yang harus

dikuasai siswa

setelah proses

pembelajaran

selesai yaitu 70 .

6) Membagi kelompok menjadi 9 kelompok, setiap kelompok beranggotakan 5 sampai 6 orang berdasarkan prestasi siswa.

7) Setiap kelompok mendapatkan

LKS yang

dijadikan sebagai

bahan acuan pembelaj aran.

\section{a. Pendahuluan}

Pada awal pelajaran untuk menarik perhatian siswa, peneliti memberikan motivasi dan apersepsi yang berhubungan dengan puisi dan menyampaikan tujuan pembelajaran, selain itu peneliti juga memberitahukan pada siswa tentang metode yang akan digunakan dalam pembelajaran kali ini yaitu menggunakan metode demonstrasi.

Setelah peneliti memberikan penjelasan singkat tentang materi pelajaran, dilanjutkan dengan pembagian kelompok. Jumlah siswa kelas $\mathrm{V}$ berjumlah 46 orang , siswa dibagi dalam 9 kelompok, yaitu 8 kelompok masing-masing beranggotakan 5 orang, dan 1 kelompok beranggotakan 6 orang. Pengelompokan tersebut diatur berdasarkan prestasi siswa sebelumnya, yaitu kelompok pandai , kelompok sedang, dan kelompok kurang pandai, siswa duduk secara berkelompok dengan teman kelompoknya masingmasing.

\section{b. Kegiatan Inti}

Kegiatan inti merupakan tahap pelaksanaan metode demonstrasi dalam pembelajaran membaca puisi. Sebelum siswa melakukan diskusi kelompok, guru memberikan penjelasan tentang membaca puisi melalui pendekatan metode demonstrasi dengan langkah pra membaca, saat membaca, dan pasca membaca. Pada langkah pra 
membaca siswa diajak memahami puisi yang akan dibacakan dengan membicarakan kosakata yang dianggap sukar bagi siswa. Kemudian dilanjutkan dengan memberi tanda jeda pada barisbaris puisi, guna mengatur pernafasan. Pada langkah saat membaca siswa diajak menyimak model yang mendemonstrasikan pembacaan puisi, pada pasca membaca siswa dapat menerapkan keterampilannya dengan pembacaan puisi yang lain atau bahkan prosa dengan aspekaspek yang telah dipelajari dalam membaca puisi. Selanjutnya siswa melakukan diskusi kelompok untuk menjawab pertanyaan pertanyaan yang ada dalam LKS.

Setelah diskusi kelompok berakhir, langkah selanjutnya mendiskusikan hasil kerja kelompok. Guru memilih kelompok yang dianggap layak untuk mempresentasikan hasil pekerjaannya di depan kelas, sedangkan kelompok lain memberikan sanggahan atau tanggapan sehingga terjadi diskusi kelas. Dalam diskusi kelas ini guru mengaris bawahi hal-hal penting yang ditanyakan kelompok, serta memberikan arahan untuk menemukan jawaban yang benar.

Setelah diskusi selesai siswa kembali duduk ditempatnya masing-masing untuk mengikuti tahap selanjutnya, yaitu siswa ditugaskan untuk berlatih membaca puisi yang berjudul " Sudirman " dan " Tamanku " sebelum diadakan tes atau penilaian, yang akan dilaksanakan pada pertemuan kedua, dengan tujuan untuk mengukur sejauh mana kemampuan siswa dalam membaca puisi.

\section{c. Penutup}

Pada kegiatan ini guru melakukan review tentang penguasaan materi dengan tanya jawab, siswa mengajukan masalah-masalah yang kurang dipahaminya, kemudian guru sebagai fasilitator membimbing siswa untuk bersama-sama memecahkan masalah tersebut, dan merumuskan kesimpulan serta melakukan refleksi terhadap kegiatan pembelajaran yang telah dilakukan, dan sebagai tindak lanjut guru memberikan tugas berupa PR.

\section{Pelaksanaan pembelajaran pada} pertemuan ke-2

Pertemuan ke 2 ini di awali dengan pengecekan kesiapan dan kehadiran siswa, serta mengkondisikan siswa agar proses pembelajaran dapat berlangsung secara kondusif, kemudian melakukan apersepsi dengan tanya jawab tentang membaca puisi.

Dalam kegiatan inti, guru menjelaskan materi secara 
singkat dan memberikan contoh bagaimana cara membaca puisi yang benar. Selanjutnya siswa disuruh kedepan seorangseorang untuk di tes membaca puisi.

Sebagai penutup, guru bersama siswa menyimpulkan materi yang telah dipelajari, kemudian guru menyampaikan kelebihan dan kekurangan siswa pada waktu di tes membaca puisi, agar siswa dapat memperbaikinya pada pertemuan berikutnya.

Observasi

Pengamatan

terhadap kegiatan penelitian dibantu oleh guru lain sebagai observer. Dari hasil observasi siklus 1, didapatkan bahwa dalam melaksanakan

pembelajaran bahasa Indonesia tentang membaca puisi dengan menggunakan metode demonstrasi, guru telah menerapkannya sesuai dengan Rencana Pelaksanaan Pembelajaran ( RPP ) yang telah disiapkan. Berdasarkan hasil pengamatan yang dilakukan oleh observer, guru terlalu cepat dalam menjelaskan dan masih kurang dalam memberikan contoh membaca puisi. Masalah lain yang didapat dari pengamatan observer adalah pada saat guru memberi contoh membaca puisi, masih ada siswa yang kurang memperhatikan.

Berdasarkan hasil pengamatan yang dilakukan oleh observer sesuai dengan data observasi pada tabel 4.2 di atas menunjukkan hal-hal sebagai berikut :

a. Proses pembelajaran yang sudah dikategorikan baik dalam pelaksanaannya adalah:

1. Mengadakan apersepsi

2. Penyajian bahan sesuai indikator

3. Antusias dalam menanggapi pertanyaan siswa

4. Ketepatan saat menggunakan media

5. Membantu meningkatkan proses pembelajaran siswa

6. Penilaian sesuai dengan yang direncanakan

7. Menginformasikan materi selanjutnya.

b. Proses pembelajaran yang sudah dikategorikan cukup dan masih perlu ditingkatkan lagi pada siklus yang ke 2 adalah sebagai berikut :

1. Menarik perhatian siswa dengan memberikan contoh atau model dalam pembacaan puisi.

2. Memberikan motivasi harus lebih jelas dan terarah. 
3. Bahan-bahan pembelajaran disajikan sesuai dengan pengalaman belajar yang direncanakan.

4. Kedalaman materi atau pokok bahasan harus lebih di gali kembali

5. Kesesuaian penggunaan strategi atau metode dengan materi perlu dikaji kembali.

6. Mengarahkan siswa agar lebih aktif dalam kegiatan diskusi kelompok.

7. Memberikan evaluasi harus sesuai dengan indikator.

8. Penguatan pada konsepkonsep yang ditemukan oleh siswa harus diperjelas lagi.

c. Proses pembelajaran yang masih kurang dan perlu ditingkatkan lagi pada pelaksanaan siklus yang ke 2 adalah sebagai berikut:

1. Memberikan acuan proses pembelajaran agar siswa lebih terarah.

2. Memberi contoh lebih jelas agar siswa mudah memahami materi pembelajaran.

Data mengenai keaktifan siswa dapat diperoleh dengan menggunakan lembar observasi pada saat proses pembelajaran berlangsung. Data mengenai keaktifan siswa pada siklus 1 dapat dilihat pada tabel 4.3

Berdasarkan hasil pengamatan yang dilakukan observer terhadap aktivitas siswa sesuai dengan tabel 4.3 di atas, bahwa siswa terlihat cukup aktif dan antusias untuk mengikuti kegiatan pembelajaran, namun masih ada beberapa anak yang hanya ngobrol dengan teman sekelompoknya. Guru harus lebih aktif dalam membimbing dan memberi rangsangan, agar siswa termotivasi untuk bertanya serta mengemukakan gagasan, dan berani tampil di depan kelas tanpa malumalu, sehingga dalam proses pembelajaran berikutnya siswa lebih aktif .

Untuk mengetahui besaran hasil belajar siswa, maka pada akhir siklus 1 yaitu hari Senin, 24 Agustus 2015 ,

Berdasarkan hasil tes membaca puisi pada siklus 1 sesuai tabel 4.4 di atas, diperoleh gambaran bahwa nilai rata-rata yang diperoleh siswa adalah 70,36 dengan 
nilai tertinggi 80 dan nilai terendah 60, dengan kriteria ketuntasan minimal (KKM ) yaitu 70. Dari 46 orang siswa yang nilai membaca puisinya mencapai KKM hanya 28 orang atau sekitar $60,86 \%$, sedangkan yang 18 orang lagi atau sekitar $39,14 \%$ masih belum tuntas. Hal ini memberikan gambaran bahwa siswa belum memahami dan menguasai teknik-teknik dalam membaca puisi, karena ketuntasan dikatakan selesai apabila materi telah diserap oleh siswa sekitar 75 $\%$. Jadi penelitian ini dilanjutkan pada siklus yang ke 2 agar penguasaan siswa terhadap materi membaca puisi lebih baik lagi sesuai yang direncanakan.

Berdasarkan tabel 4.4 terlihat bahwa nilai rata-rata yang diperoleh siswa adalah 70,36 dengan nilai tertinggi 80 dan nilai terendah 60 . Siswa yang hasil belajarnya mencapai KKM ada 28 orang atau sekitar 60,86 \%, dari nilai KKM yang telah ditetapkan yaitu 70. Hal ini memberikan gambaran bahwa ketuntasan hasil belajar siswa dalam membaca puisi dari tes awal ( pra siklus ) ke siklus 1 mengalami peningkatan yaitu $23,91 \%$.

\section{Refleksi}

Berdasarkan analisis data di atas, masih terdapat kekurangan-kekurangan pada siklus 1. Kekerungan kekurangan tersebut antara lain:

1) Guru kurang memotivasi siswa.

2) Guru terlalu cepat dalam menjelaskan materi.

3) Dalam memberikan contoh membaca puisi yang dilakukan guru kurang menarik perhatian siswa.

4) Kemampuan siswa dalam membaca puisi belum terlihat menonjol, karena masih ada 18 orang siswa atau 39,14 \% yang nilainya masih di bawah KKM.

Dengan adanya kekurangankekurangan tersebut, maka perlu adanya perbaikanperbaikan dalam kegiatan pembelajaran pada siklus 2 .

Hal-hal yang perlu diperhatikan pada siklus 2 adalah :

1) Penjelasan materi harus lebih jelas dan mudah dipahami oleh siswa.

2) Pemberian contoh dan peragaan dalam membaca puisi harus lebih optimal atau menggunakan model untuk memotivasi siswa.

3) Presentase kelompok harus lebih efektif. 
4) Mengarahkan siswa yang kurang aktif dalam kelompok.

5) Hubungan siswa dengan anggota kelompok harus lebih ditingkatkan.

6) Bimbingan guru harus lebih merata keseluruh kelompok.

7) Mendidik tanggung jawab siswa. Pencapaian tujuan pembelajaran pada siklus 1 ditunjukkan oleh perolehan rata-rata nilai siswa yakni 70,36 atau berada pada kualifikasi cukup, namun belum mencapai target ketuntasan minimal karena masih ada 18 orang siswa atau $39,14 \%$ dari 46 siswa yang nilainya di bawah ketuntasan minimal. Tetapi bila dilihat dari data hasil belajar siswa pada siklus 1, diperoleh gambaran bahwa siswa merespon positif terhadap pembelajaran yang telah diterapkan, hal ini terlihat dari nilai siswa yang diatas KKM ada 28 orang atau $60,86 \%$ dari seluruh siswa yang terdiri dari 46 orang.

\section{Siklus-2}

Siklus ke 2 dilalsanakan dua kali pertemuan, pertemuan ke satu dilaksanakan pada hari Jum'at, 2 Oktober 2015 pada jam pelajaran ke 1 dan ke 2 selama 70 menit, dan pertemuan kedua dilaksanakan pada hari Senin, 12 Oktober 2015 pada jam ke -5 dan ke-6 selama 70 menit di kelas $\mathrm{V}$, pada pertemuan kedua dilakukan tes uji kompetensi, yaitu siswa di tes membaca puisi secara individu di depan kelas. Kegiatan yang dilakukan peneliti pada siklus 2 adalah sebagai berikut :

\section{Perencanaan}

Pada perencanaan siklus 2 diawali dengan mengidentifikasi temuan-temuan hasil dari siklus 1, dan dilanjutkan dengan pengembangan Rencana Persiapan Pembelajaran untuk siklus 2 dengan menerapkan metode demonstrasi. Adapun langkah-langkah kegiatan yang dilakukan adalah sebagai berikut :

1) Membuat Rencana Pelaksanaan Pembelajaran ( RPP ), dengan pokok bahasan membaca puisi dengan menerapkan metode demonstrasi berdasarkan pada hasil refleksi siklus 1 .

2) Membuat lembar observasi terhadap guru dan siswa. Lembar observasi ini digunakan untuk melihat aktivitas guru dan siswa ketika proses belajar mata pelajaran bahasa Indonesia berlangsung.

3) Membuat angket siswa.

4) Membuat lembar kerja siswa ( LKS )

5) Membuat alat evaluasi untuk tes pada tindakan siklus 2 .

\section{Tindakan}

Pada pelaksanaan tindakan siklus 2 dilaksanakan dalam dua kali pertemuan. Pelasanaan pembelajaran pada pertemuan ke satu

Adapun langkah pembelajaran pada pertemuan 1 adalah sebagai berikut :

1) Guru terlebih dahulu meneliti tingkat kesiapan siswa, 
mengecek absensi

siswa, serta mengkondisikan kelas agar proses pembelajaran dapat

berlangsung secara kondusif.

2) Melakukan apersepsi dengan tanya jawab tentang materi yang akan diajarkan.

3) Memberikan motivasi agar peserta didik mampu terlibat aktif dalam seluruh proses pembelajaran.

4) Pembagian kelompok menjadi 9 kelompok berdasarkan pada kemampuan masing-masing siswa.

\section{a) Pendahuluan}

Guru memberi penjelasan singkat mengenai langkahlangkah pembelajaran, dilanjutkan dengan pembagian kelompok. Siswa kelas V berjumlah 46 orang dibagi menjadi 9 kelompok, 8 kelompok masing-masing beranggotakan 5 orang dan 1 kelompok beranggotakan 6 orang. Pengelompoka tersebut diatur berdasarkan prestasi siswa sebelumnya, yaitu kelompok pandai, kelompok sedang, dan kelompok kurang pandai.

Setelah tiap kelompok siap, dan masing-masing kelompok telah menerima LKS, lalu guru mengarahkan siswa untuk memperhatikan dan menyimak LKS tersebut, kemudian guru menyampaikan tujuan pembelajaran khusus yang harus dicapai setelah proses pembelajaran selesai. Kegiatan pendahuluan ditutup dengan apersepsi, berbagai rangsangan disampaikan guru sebagai pemancing kreativitas siswa dalam berfikir.

\section{b) Kegiatan Inti}

Pada kegiatan inti, guru menstimulasi siswa dengan beberapa pertanyaan yang disajikan dalam LKS. Pertanyaan ini diberikan sebagai petunjuk untuk membimbing siswa supaya memahami puisi yang akan dibacakan dengan cara menentukan kosakata yang dianggap sukar oleh siswa, kemudian memberi tanda jeda pada baris - baris puisi, gunanya untuk mengatur pernafasan pada waktu membacakan puisi. Pada saat siswa sedang berdiskusi, siswa diajak untuk menyimak model yang mendemonstrasikan pembacaan puisi, lalu apa yang mereka saksikan didiskusikannya dalam kelompok.

Pada saat diskusi berlangsung guru mamantau, mengarahkan dan membantu siswa yang mengalami kesulitan. Pada pembelajaran siklus 2 ini siswa lebih aktif bertanya, komunikasi antar siswa pun lebih terjalin. Dalam proses menjawab soal LKS siswa tidak terlalu banyak yang bertanya, hal ini mungkin disebabkan siswa telah memahami materi tentang membaca puisi dan ada keterkaitan dengan materi 
pelajaran pada pertemuan sebelumnya.

Setelah diskusi kelompok selesai, guru memilih beberapa kelompok untuk mempresentasikan hasil kerja kelompok di depan kelas, sedangkan kelompok lain mengajukan sanggahan atau tanggapan terhadap hasil pekerjaan temannya sehingga terjadi diskusi kelas. Dalam diskusi kelas tersebut guru berperan sebagai pasilitator memandu jalannya diskusi, dan meluruskan jawaban yang benar, sehingga terjadi diskusi yang terarah.

\section{c) Penutup}

Tahapan ini diisi dengan kegiatan review tentang penguasaan materi, yaitu dengan melakukan tanya jawab, kemudian guru membimbing siswa untuk merumuskan kesimpulan dan melakukan refleksi terhadap kegiatan pembelajaran yang telah dilakukan. Sebagai tindak lanjut siswa diberi tugas pekerjaan rumah, kemudian guru menginformasikan materi pelajaran yang akan disampaikan dalam pertemuan berikutnya.

\section{Pelaksanaan pembelajaran pada} pertemuan ke 2

Pertemuan ke 2 ini di awali dengan pengecekan kesiapan dan kehadiran siswa, serta mengkondisikan siswa agar proses pembelajaran dapat berlangsung secara kondusif, kemudian melakukan apersepsi dengan tanya jawab tentang membaca puisi. Dalam kegiatan inti, guru menjelaskan materi secara singkat dan memberikan contoh bagaimana cara membaca puisi yang benar. Selanjutnya siswa disuruh kedepan seorang-seorang untuk di tes membaca puisi. Sebagai penutup, guru bersama siswa menyimpulkan dan melakukan refleksi terhadap kegiatan pembelajaran yang telah dilakukan. Sebagai tindak lanjut siswa diberi tugas PR, kemudian guru menginformasikan materi pelajaran yang akan disampaikan dalam pertemuan berikutnya.

\section{Observasi}

Pada siklus 2 ini dalam kegiatan pembelajaran guru telah melakukan perbaikanperbaikan, yaitu :

1) Pada saat siswa berdiskusi mengerjakan LKS guru berkeliling mengamati aktivitas siswa dalam kelompok, membimbing dan mengarahkan siswa yang mengalami kesulitan. Pada pembelajaran siklus 2 ini siswa lebih aktif 
bertanya, komunikasi antar siswa pun lebih terjalin. Dalam proses menjawab soal pada LKS tidak terlalu banyak yang bertanya, hal ini mungkin dikarenakan keterkaitan materi pelajaran pada pertemuan sebelumnya.

2) Pengamatan terhadap kegiatan penelitian dibantu oleh guru lain sebagai observer.Observer melakukan pengamatan terhadap proses pembelajaran secara keseluruhan menyangkut aktivitas guru melakukan pembelajaran maupun proses belajar siswa. Di bawah ini disajikan data hasil pengamatan observer terhadap aktivitas guru pada siklus Berdasarkan hasil observasi aktivitas guru dalam menyampaikan materi tentang membaca puisi melalui metode demonstrasi, pada tabel 4.5 di atas menunjukkan bahwa proses pembelajaran sesuai dengan rencana, sehingga hasilnya optimal.

Di bawah ini penulis sajikan hasil pengamatan observer tentang aktivitas siswa pada siklus 2,

Berdasarkan hasil pengamatan yang dilakukan observasi terhadap aktivitas siswa sesuai dengan tabel 4.6 di atas , bahwa siswa terlihat sangat aktif dan antusias untuk mengikuti kegiatan pembelajaran, begitu juga komunikasi antara siswa dengan guru, hal ini terbukti siswa tidak segan lagi untuk bertanya halhal yang kurang dipahami. Semua siswa mengikuti proses pembelajaran dengan baik, sehingga hasilnya sangat memuaskan sesuai dengan apa yang diharapkan. Untuk mengetahui besaran hasil belajar siswa, maka pada akhir siklus 2 dilakukan tes membaca puisi. Berdasarkan hasil tes formatif ( tes membaca puisi ) pada siklus 2 sesuai tabel 4.7 di atas, diperoleh gambaran hasil prestasi belajar siswa dengan !criteria ketuntasan minimal ( KKM ) 70, yakni nilai rata-rata yang diperoleh siswa kelas VC adalah 81,41 dengan nilai tertinggi 93 dan nilai terendah 70 . Siswa yang nilai prestasinya diatas KKM ada 46 orang atau $100 \%$. Hal ini memberikan gambaran bahwa ketuntasan hasil belajar siswa mengalami peningkatan dari siklus 1 ke siklus 2 yaitu sekitar 39,13\%. Dengan melihat perolehan nilai tersebut di atas memberikan gambaran bahwa materi tentang membaca puisi sudah dipahami oleh siswa, disamping itu siswa pun mulai menyukai pelajaran membaca puisi maupun menulis puisi. 


\section{Refleksi}

Kegiatan refleksi dilakukan setelah proses pembelajaran berakhir, dihadiri oleh observer dengan memperhatikan masukan-masukan dari observer tentang kesulitan peserta didik dan hasil belajar siswa secara keseluruhan. Pada siklus 2 pembelajaran sedikit lebih lancar dari siklus sebelumnya, permasalahan yang ada telah berhasil diperbaiki pada siklus ini, diantaranya :

1) Sikap dan aktifitas siswa sudah tidak canggung saat mengikuti proses pembelajaran.

2) Siswa merasa puas dalam belajar, karena dalam proses pembelajaran ditunjang oleh media pembelajaran yang dapat menarik minat siswa, sehingga dapat meningkatkan hasil belajar siswa.

3) Siswa tidak malu dan tidak canggung lagi untuk tampil di depan kelas.

4) Pada siklus kedua ini, proses belajar yang dilakukan baik secara individu maupun kelompok mampu meningkatkan hasil belajar semua peserta didik.

5) Pelaksanaan pembelajaran sesuai dengan RPP yang dibuat.

Pencapaian tujuan pembelajaran pada siklus 2 ditunjukkan dengan perolehan nilai rata-rata yakni 81,41 dan 46 orang siswa atau $100 \%$ yang nilai prestasi belajarnya mencapai KKM, hal ini menunjukkan bahwa prestasi hasil belajar siswa kelas $\mathrm{V}$ berada pada kualifikasi baik

\section{Pembahasan Hasil Pembelajaran}

Keberhasilan suatu proses pembelajaran dapat dilihat dari hasil belajar yang diperoleh melalui tes akhir, oleh karena itu untuk menganalisis hasil implementasi metode demonstrasi di kelas V SD Negeri Talun dilakukan dengan cara menganalisis hasil tes akhir tersebut. Tes dilaksanakan secara lisan yaitu tes perbuatan, karena materi yang akan di ujikan adalah membaca puisi. Berdasarkan deskripsi penelitian yang telah penulis kemukakan di awal bab ini, menunjukkan bahwa nilai rata-rata kelas yang diperoleh siswa pada pra siklus hanya 65,37 , dan siswa yang nilainya diatas KKM hanya 17 orang atau $37 \%$. Hal ini berarti hasil belajar pada prasiklus belum berhasil, masih sangat kurang dari batas perolehan nilai berdasarkan ketuntasan minimal yaitu 70 .

Sesuai dengan ketuntasan minimal yang hams dicapai, siswa yang nilainya mencapai KKM pada prasiklus yaitu 17 orang atau $37 \%$, dan siswa yang nilainya belum mencapai KKM sebanyak 29 orang atau $63 \%$. Untuk mendapatkan gambaran yang lebih jelas

Berdasarkan hasil tes pada siklus 1, diperoleh nilai rata-rata kelas sebesar 70,36. Siswa yang nilai prestasinya mencapai KKM ada 28 orang atau 60,86\%, sedangkan kualifikasi siswa yang belum 
mencapai ketuntasan minimal ada 18 orang atau 39,14 \%. Hal ini menunjukkan bahwa hasil belajar pada siklus 1 belum berhasil dengan baik, kurangnya keberhasilan ini disebabkan oleh berbagai hal antara lain siswa masih malu-malu atau kurang percaya diri tampil di depan kelp untuk membacakan sebuah puisi, dan volume suara, ekspresi serta intonasi masi kurang. Ketidakmampuan yang dialami siswa disebabkan kurangnya latihan yang rutin dan guru kurang memberi contoh dalam membaca puisi. Agar mendapat gambaran yang lebih jelas tentang hasil pembelajaran siklus 1 .

Pada siklus 2 diperoleh data nilai rata-rata prestasi belajar siswa adalah 81,41 ( sangat baik ). Siswa yang mencapai ketuntasan minimal sebanyak 46 orang atau $100 \%$, ini menunjukkan bahwa proses implementasi metode demonstrasi dalam membaca puisi di kelas V SD Negeri Talun yang penulis laksanakan berhasil dengan sangat baik. Hal ini memberikan gambaran bahwa prestasi hasil belajar siswa mengalami peningkatan yang signifikan dari siklus 1 ke siklus 2 yaitu 39,14 \%. Agar mendapat gambaran yang lebih jelas tentang hasil pembelajaran pada siklus 2, maka penulis sajikan pada tabel 4.10 berikut ini :

Data yang diperoleh dari hasil penelitian di atas adalah data kuantitatif yang diperoleh dari hasil tes. Data-data tersebut berupa skor kemampuan siswa pada pra siklus, siklus 1, dan siklus 2. Agar data-data tersebut lebih bermakna dan jelas. Berikut ini adalah tabel rekapitulasi nilai peningkatan kemampuan siswa dan perolehan nilai prestasi hasil belajar saat prasiklus, siklus 1 , dan siklus 2

\section{Pembuktian Hipotesis}

Berdasarkan pada hasil tes yang penulis ketahui bahwa siswa yang nilai prestasi belajarnya mencapai KKM atau tuntas mulai dari prasiklus, siklus 1 , dan siklus 2 terjadi peningkatan yang signifikan, yaitu dari prasiklus ke siklus 1 mengalami peningkatan $23,91 \%$, dan dari siklus 1 ke siklus 2 mengalami peningkatan $39,13 \%$.

Hal ini dapat disimpulkan bahwa hipotesis kerja ( $\mathrm{Hi}$ ) yang penulis susun, bahwa pendekatan metode demonstrasi sangat efektif untuk meningkatakan kemampuan dan keterampilan siswa dalam membaca puisi di kelas V SD Negeri Talun Kecamatan Cipatat Kabupaten Bandung Barat.

\section{E. SIMPULAN DAN REKOMENDASI}

\section{Simpulan}

Berdasarkan hasil penelitian dan pembahasan maka secara umum dapat dikemukakan simpulan sebagai berikut : bahwa penggunaan pendekatan metode demonstrasi merupakan pilihan yang tepat dan 
efektif untuk meningkatkan kemampuan dan keterampilan siswa dalam membaca puisi di kelas V SD Negeri Talun Kecamatan Cipatat Kabupaten Bandung Barat. Hal ini dibuktikan dengan :

1. Nilai rata-rata pada prasikius 65,41 , dan siswa yang mencapai ketuntasan ada 17 orang atau $36,9 \%$. Nilai ratarata pada siklus 1 adalah 70,36 dan siswa yang mencapai ketuntasan pada siklus 1 ada 28 orang atau sekitar $60,86 \%$, hal ini mengalami peningkatan dari prasiklus ke siklus 1 yaitu 23,91 \%. Pada siklus 2 perolehan nilai rata-ratanya 81,41 dengan jumlah siswa yang mencapai ketuntasan ada 46 orang atau 100\%, hal ini terjadi peningkatan dari siklus 1 ke siklus 2 adalah 39,13\%. Simpulan tersebut didukung oleh hasil pembuktian hipotesis penelitian, dari 46 orang siswa yang berhasil mendapatkan nilai diatas KKM yang telah ditetapkan yaitu 70, ternyata 46 orang atau $100 \%$ siswa memperoleh nilai di atas KKM. Dengan demikian telah terjadi perubahan yang signifikan pada hasil belajar siswa, Hal ini membuktikan bahwa sebelum dan setelah diberi perlakuan dengan menerapkan metode demonstrasi dapat meningkatkan kemampuan dan keterampilan siswa dalam membaca puisi di kelas V SD Negeri Talun Kecamatan Cipatat Kabupaten Bandung Barat. Metode demonstrasi yang didukung penampilan model dapat meningkatkan kemampuan dan keterampilan membaca puisi, sehingga dapat dijadikan sebagai alternatif metode pembelajaran membaca puisi, serta dapat meningkatkan kreatifitas siswa sesuai dengan kemampuan diri sendiri.

\section{Saran-saran}

Untuk meningkatkan kualitas proses pembelajaran bahasa Indonesia, hendaknya:

a) Guru berupaya untuk menciptakan dan mengembangkan proses pembelajaran Bahasa Indonesia yang dapat menyenangkan siswa, sehingga mereka mempunyai sikap positif terhadap pelajaran bahasa Indonesia khususnya membaca puisi, yaitu dengan menerapkan metode demonstrasi dalam pembelajarannya.

b) Metode demonstrasi adalah salah satu metode pembelajaran yang dapat diterapkan dalam mats pelajaran lain selain bahasa Indonesia, karena metode ini menuntut siswa lebih aktif, kreatif, kritis, dan inovatif

c) Guna menunjang pendekatan metode demonstrasi, hendaknya guru perlu mempersiapkan diri sebagai model, supaya dapat mendemonstrasikan dengan baik dihadapan siswanya.

\section{F. REFERENSI}

Aminuduin , 1987.

Pengantar Apresiasi 
Karya Sastra: Sinar

Baru Depdiknas,

2008: 106 . Peraturan

Mentri Pendidikan

Nasional

Muslihuddin, 2015. Kiat Sukses Melakukan Penelitian Tindakan Kelas dan Sekolah. Bandung : Rizqi Press

Syaiful Bahri Djamarah, 2000. Guru dan Anak Didik dalam Interaksi Edukatif, Jakarta : PT Rineka Cipta

Tarigan, HG, dkk. 1990. Membaca dalam Kehidupan, Bandung : Angkasa

Tim Bina Karya Guru. 2007. Bina Bahasa Indonesia, untuk SD Kelas 5. Penerbit Erlangga

http : /1 Luminutu. Multiply. Com. Diakses pada tanggal 8 Agustus 2015 